\title{
Inactivation of NMDA Channels in Cultured Hippocampal Neurons by Intracellular Calcium
}

\author{
Pascal Legendre, ${ }^{1, a}$ Christian Rosenmund, ${ }^{1,3}$ and Gary L. Westbrook ${ }^{1,2}$ \\ ${ }^{1}$ Vollum Institute and Departments of ${ }^{2}$ Neurology and ${ }^{3}$ Physiology, Oregon Health Sciences University, \\ Portland, Oregon 97201
}

\begin{abstract}
Calcium-dependent inactivation of NMDA channels was examined on cultured rat hippocampal neurons using wholecell voltage-clamp and cell-attached single-channel recording. An ATP regeneration solution was included in the patch pipette to retard current "rundown." In normal $\left[\mathrm{Ca}^{2+}\right]_{0}(1-2$ $\mathrm{mm}$ ) and $10 \mu \mathrm{M}$ glycine, macroscopic currents evoked by 15 sec applications of NMDA (10 $\mu \mathrm{M})$ inactivated slowly following an initial peak. At $-50 \mathrm{mV}$ in cells buffered to $\left[\mathrm{Ca}^{2+}\right]_{i}$ $<10^{-8} \mathrm{M}$ with $10 \mathrm{mM}$ EGTA, the inactivation time constant $\left(\tau_{\text {inact }}\right)$ was $\approx 5 \mathbf{s e c}$. Inactivation did not occur at membrane potentials of $+40 \mathrm{mV}$ and was absent at $\left[\mathrm{Ca}^{2+}\right]_{0} \leq 0.2 \mathrm{mM}$, suggesting that inactivation resulted from transmembrane calcium influx. The percentage inactivation and $\boldsymbol{\tau}_{\text {inact }}$ were dependent on $\left[\mathrm{Ca}^{2+}\right]_{0^{\text {. }}}$. The $\tau_{\text {inact }}$ was also longer with BAPTA in the whole-cell pipette compared to EGTA, suggesting that $\tau_{\text {inact }}$ reflects primarily the rate of accumulation of intracellular calcium.
\end{abstract}

Inactivation was incomplete, reaching a steady state level of $40-50 \%$ of the peak current. At steady state, block of open NMDA channels with MK-801 ((+)-5-methyl-10,11-dihydro-5H-dibenzo[a,d]cyclohepten-5,10-imine) completely blocked subsequent responses to NMDA, suggesting that "inactivated" channels can reopen at steady state. Inactivation was fully reversible in the presence of ATP but was not blocked by inhibiting phosphatases or proteases. In cellattached patches, transient increases in $\left[\mathrm{Ca}^{2+}\right]_{i}$ following cell depolarization also resulted in inactivation of NMDA channels without altering the single-channel conductance. This suggests that $\mathrm{Ca}^{2+}$-dependent inactivation occurs in intact cells and can be triggered by calcium entry through nearby voltage-gated calcium channels, although calcium entry through NMDA channels was more effective. We suggest that $\left[\mathrm{Ca}^{2+}\right]$, transients induce NMDA channel inactivation by binding to either the channel or a nearby regulatory protein to alter channel gating. This mechanism may play a role in downregulation of postsynaptic calcium entry during sustained synaptic activity.

\footnotetext{
Received June 15, 1992; reviscd Aug. 10, 1992; accepted Aug. 14, 1992.

This work was supported by U.S. Public Health Service Grants NS26494 and MH46613 and the McKnight Foundation (G.L.W.), and by NATO Foundation and INSERM (P.L.). We thank Drs. Robin Lester and Craig Jahr for helpful discussions, and Jeff Volk for preparation of cell cultures. P.L. and C.R. contributed equally to these experiments.

Correspondence should be addressed to Gary L. Westbrook, Vollum Institute, L474, Oregon Health Sciences University, 3181 SW Sam Jackson Park Road, Portland, OR 97201.

aPresent address: Institut Pasteur, Departement des Biotechnologies, INSERM U 261, 75724 Paris Cedex 15, France.

Copyright (C) 1993 Society for Neuroscience $0270-6474 / 93 / 130674-11 \$ 05.00 / 0$
}

[Key words: NMDA, glutamate receptors, calcium, desensitization, ion channels, hippocampus]

Calcium acting as a second messenger plays a key role in neuronal function. As a result, intracellular calcium concentrations are tightly regulated by a series of cellular buffers and pumps (Carafoli, 1987; Blaustein, 1988). Thus, in most cases the effects of intracellular calcium transients, either from transmembrane influx or via release from intracellular stores, are relatively localized near the source of calcium entry or release. For examplc, $\mathrm{Ca}^{2+}$ transients in "domains" near presynaptic release sites provide the brief, high concentrations of calcium necessary for transmitter release (e.g., Smith and Augustine, 1988; Llinas et al., 1992). Focal increases in calcium in dendritic spines also occur following synaptic excitation (Müller and Connor, 1991). This compartmentalization has important functional consequences. For example, the induction of long-term potentiation in the CAl region of the hippocampus is triggered by postsynaptic calcium influx through NMDA, whereas depolarization and opening of voltage-dependent calcium channels is not as effective (Nicoll et al., 1988).

One target of intracellular calcium is voltage-dependent and ligand-gated ion channels (e.g., Scubon-Mulieri and Parsons, 1977; Chad et al., 1984; Inoue et al., 1986; Behrends et al., 1988; Marchenko, 1991). Calcium increases the activity of $\mathrm{Ca}^{2+}$ dependent $\mathrm{K}^{+}$or $\mathrm{Cl}^{-}$channels (Marty, 1989), but decreases the activity of voltage-dependent calcium channels (Chad, 1989). Calcium can bind directly to ion channels or act via $\mathrm{Ca}^{2+}$ dependent enzymes (Chad and Eckert, 1986; Marty, 1989; Armstrong et al., 1991). $\mathrm{Ca}^{2+}$-dependent inactivation of calcium channels appears to involve the action of a phosphatase, but other calcium-dependent processes may also contribute (Chad and Eckert, 1986; Belles et al., 1988; Korn and Horn, 1989). For calcium-permeable channels, inactivation could limit transmembrane calcium flux during prolonged depolarization, and thus could be an important protective factor to minimize $\mathrm{Ca}^{2+}$. induced neuronal death (e.g., Choi, 1988; Lynch and Seubert, 1989).

The NMDA receptor is subject to modulation by a number of extracellular agents including $\mathrm{Mg}^{2+}$, glycine, $\mathrm{Zn}^{2+}$, and protons (for review, see Mayer and Westbrook, 1987; Collingridge and Lester, 1989), but intracellular regulation is much less clear. Several experiments have suggested that calcium can lead to inactivation (or desensitization) of the NMDA channel, although both intracellular (Mayer and Westbrook, 1985; Mayer et al., 1987) and extracellular mechanisms have been proposed (Zorumski et al., 1989; Clark et al., 1990).

We used whole-cell voltage clamp and cell-attached patch 
recording to examine calcium-dependent inactivation of NMDA receptors in cultured hippocampal neurons. Calcium influx through NMDA channels resulted in slow inactivation that reached a maximum of $50 \%$ of the initial peak current. The rate of inactivation appeared to reflect the rate of intracellular calcium accumulation rather than the kinetics of the $\mathrm{Ca}^{2+}$-dependent process, and did not appear to involve $\mathrm{Ca}^{2+}$-dependent proteases or phosphatases. We suggest that calcium binds to either the NMDA channel or a nearby regulatory protein to regulate the kinetics of the NMDA channel.

\section{Materials and Methods}

Cell cultures. Cultures of hippocampal neurons were prepared as previously described (Legendre and Westbrook, 1990). Hippocampi from postnatal day 1 Sprague-Dawley rat pups were incubated in a lowcalcium saline with papain (5-20 U/ml; Worthington Biochemicals) for $1 \mathrm{hr}$. The papain was inactivated in bovine serum albumin and trypsin inhibitor; the tissue was mechanically dissociated and plated onto a confluent layer of hippocampal astrocytes. The culture medium contained minimum essential medium, $0.6 \%$ glucose, $5 \%$ heat-inactivated horse serum (Hyclone), and a supplement including $200 \mu \mathrm{g} / \mathrm{ml}$ transferrin, $200 \mu \mathrm{M}$ putrescine, $60 \mathrm{~nm}$ sodium selenite, $40 \mathrm{~nm}$ progesterone, $40 \mathrm{ng} / \mathrm{ml}$ corticosterone, $20 \mathrm{ng} / \mathrm{ml}$ triiodothyronine, and $10 \mu \mathrm{g} / \mathrm{ml}$ insulin. Cultures were treated $1 \mathrm{~d}$ after plating with a mixture of 5 -fluoro2-deoxyuridine and uridine ( 15 and $35 \mu \mathrm{g} / \mathrm{ml}$, respectively) to suppress overgrowth of background cells; half-changes of medium were done twice weekly.

Whole-cell recording and drug delivery. Whole-cell voltage-clamp recordings were performed on neurons after 1-2 weeks in culture. The extracellular solution contained (in $\mathrm{mM}$ ) $\mathrm{Na}^{+}, 162 ; \mathrm{K}^{+}, 2.4 ; \mathrm{Ca}^{2+}, 1.3$ $\mathrm{Mg}^{2+}, 0 ; \mathrm{Cl}^{-}, 167$; HEPES, 10 ; glucose, $10 ; \mathrm{pH}$ adjusted to 7.3 . Tetrodotoxin $(0.5 \mu \mathrm{M})$, strychnine $(2 \mu \mathrm{M})$, and picrotoxin $(50 \mu \mathrm{M})$ were added to block spontaneous electrical activity and glycine/GABA channels, respectively. Glycine $(10 \mu \mathrm{M})$ was also added to facilitate activation of NMDA-evoked currents. In some experiments, $\left[\mathrm{Ca}^{2+}\right]_{o}$ was varied between nominally zero and $50 \mathrm{~mm}$; sodium was adjusted to keep the osmolarity at $325 \mathrm{mOsm}$. Patch pipettes for whole-cell recording were pulled from borosilicate glass (TWF 150, World Precision Instruments), coated with Sylgard, and fire polished. DC resistances were 2-10 M . Pipette solutions contained (in mM) $\mathrm{CsCl}$, 95; EGTA, 10; HEPES, 10; and an ATP "regeneration" solution (Forscher and Oxford, 1985; MacDonald et al., 1989) including $\mathrm{Na}-\mathrm{ATP}, 4 ; \mathrm{MgCl}_{2}, 4$; disodium phosphocreatine, 20; and creatine phosphokinase, $50 \mathrm{U} / \mathrm{ml}$. Patch solutions were prepared daily from frozen stocks and kept on ice until use. The $\mathrm{pH}$ was adjusted to 7.2 with $\mathrm{CsOH}$; osmolarity was adjusted to 295 mOsm. In some experiments, intracellular calcium was increased using $\mathrm{Ca}$ /EGTA mixtures; the pipette calcium concentration was calculated assuming an EGTA dissociation constant of $10^{-7} \mathrm{M}$. The chamber was continuously perfused $(1-2 \mathrm{ml} / \mathrm{min})$ at room temperature $\left(\approx 20^{\circ} \mathrm{C}\right)$. Whole-cell currents were recorded using an Axopatch 1B (Axon Instruments) with the current filtered at $10 \mathrm{kHz}$. Membrane current records were monitored on a chart recorder and stored on cither on computer or videotape (VR10, Instrutech Corp.). For display purposes, currents were filtered at $30-100 \mathrm{~Hz}$.

NMDA (1-300 $\mu \mathrm{M})$ was dissolved in the extracellular solution and applied via an array of flow pipes $(400 \mu \mathrm{m}$ i.d.) positioned within $100-$ $200 \mu \mathrm{m}$ of the cell. Each flow pipe was controlled by solenoid values; solutions were changed by simultaneously closing one valve and opening another. The solution exchange time constant was $<20 \mathrm{msec}$ as measured by change in membrane current evoked by kainic acid in two concentrations of sodium (Vyklický et al., 1990). Ultrapure calcium and sodium salts (Aldrich) were used in the flow pipes for drug delivery. In experiments with $\mathrm{F}^{-}, \mathrm{CsF}(50 \mathrm{~mm})$ was substituted isotonically for $\mathrm{CsCl}$ in the patch solution. Stock solutions of calmidazolium $(10 \mathrm{~mm}$ in dimethyl sulfoxide, Calbiochem) and okadaic acid $(100 \mu \mathrm{g} / \mathrm{ml}$ in $\mathrm{N}, \mathrm{N}-$ dimethylformamide, Calbiochem) were diluted in to the pipette solution before each experiment. Fifteen minutes were allowed after the start of whole-cell recording for the substance to diffuse into the cell; this is more than sufficient to allow exchange of these low-molecular-weight compounds (Oliva et al., 1988; Pusch and Neher, 1988). The access resistance was regularly monitored with small voltage steps. Excitatory amino acids were obtained from Cambridge Research Biochemicals or Tocris Neuramin; other chemicals were obtained from Sigma.
In some experiments, voltage jumps were used to evoke voltagedependent calcium currents. In these experiments extracellular calcium was increased to $5 \mathrm{~mm}$ during the voltage jump. Jump protocols and membrane currents were recording on an IBM-PC using pCLAMP software (version 5.5). No leak subtraction was used.

Single-channel recording. Cell-attached recording was made using relatively large patch electrodes (1-2 M $)$ containing $\mathrm{Ca}^{2+}$-free extracellular solution buffered with $10 \mathrm{mM}$ EGTA. L-Glutamate $(1 \mu \mathrm{M})$ and glycine $(10 \mu \mathrm{M})$ were included in the patch pipette. Single-channel currents were stored on a digital data recorder (VR 10, Instrutech), and then replayed, filtered at $2 \mathrm{kHz}$ (eight-pole Bessel, Frequency Devices), digitized at $10 \mathrm{kHz}$, and analyzed on an IBM AT clone using pCLAMP software (version 5.5). Single-channel conductance was checked for each patch using the observed reversal potential. Software developed by John Clements (AXOGRAPH, Axon Instruments) was used to plot cumulative point-per-point amplitude histograms and obtain estimates of channel opening probability $(n p)$ where $n$ is the number of channels and $p$ is the probahility of opening for a single channel.

Results are presented as mean values \pm SD. Statistical comparisons were made using the Student's $t$ test.

\section{Results}

Whole-cell recordings were performed on hippocampal neurons after 7-14 $\mathrm{d}$ in culture. When neurons were clamped near the resting potential in normal extracellular calcium $\left(\left[\mathrm{Ca}^{2+}\right]_{o}=1-\right.$ $2 \mathrm{~mm}$ ), NMDA-evoked inward currents in $\mathrm{Mg}^{2+}$-free solutions showed $\mathrm{Ca}^{2+}$-dependent inactivation in all neurons tested. In order to limit rundown of the NMDA responses during long recordings, an ATP "regeneration" solution (Forscher and Oxford, 1985; MacDonald et al., 1989) was added to the intracellular solution. This allowed stable recordings for periods up to $30 \mathrm{~min}$. In most experiments, $15 \mathrm{sec}$ drug applications were delivered every $100 \mathrm{sec}$ to reduce cumulative effects of repeated applications.

\section{Slow voltage-dependent inactivation by $\mathrm{Ca}^{2+}$}

Both glycine-dependent and glycine-independent desensitization of the NMDA receptor have been observed that are not calcium dependent (Mayer et al., 1989; Sather et al., 1990). In order to examine $\mathrm{Ca}^{2+}$-dependent inactivation in isolation, neurons were voltage clamped at $-50 \mathrm{mV}$ in the presencc of low concentrations of NMDA $(1-10 \mu \mathrm{M})$ and high concentrations of glycine $(10 \mu \mathrm{M})$. Under these conditions, there was little apparent desensitization/inactivation of the NMDA-evoked inward currents in low $\left[\mathrm{Ca}^{2+}\right]_{o}$ (Fig. 1A). However, when $\left[\mathrm{Ca}^{2+}\right]_{o}$ was raised to $1.3 \mathrm{~mm}$, a slow current relaxation appeared that approached a steady state level within $10-15 \mathrm{sec}$. We have called this relaxation "inactivation" to avoid confusion with other forms of NMDA receptor desensitization. When the membrane potential was shifted to $+40 \mathrm{mV}$, the $\mathrm{Ca}^{2+}$-dependent relaxation was markedly reduced (Fig. $1 A$ ).

A small residual relaxation was often observed even at positive membrane potentials. This relaxation was unaffected by changes in $\left[\mathrm{Ca}^{2+}\right]_{o}$, was much slower than the $\mathrm{Ca}^{2+}$-dependent inactivation, and was not further analyzed. At a holding potential of $-50 \mathrm{mV}$, there was also a small decrease in the peak current amplitude in $1.3 \mathrm{~mm}\left[\mathrm{Ca}^{2+}\right]_{o}(13 \pm 4 \%, n-14)$ compared to $0.2 \mathrm{mM}\left[\mathrm{Ca}^{2+}\right]_{0}$. This is consistent with a reduction in the single-channel conductance of the NMDA channels as $\left[\mathrm{Ca}^{2+}\right]_{\circ}$ increases (Jahr and Stevens, 1987; Ascher and Nowak, 1988).

We examined several simple possible explanations for $\mathrm{Ca}^{2+}$ dependent inactivation including changes in ion gradients, activation of secondary $\mathrm{Ca}^{2+}$-dependent conductances, or a $\mathrm{Ca}^{2+}$. induced change in agonist affinity. However, the reversal potential was unaffected as shown by a $130 \mathrm{msec}$ ramp $(1 \mathrm{mV} /$ 
A

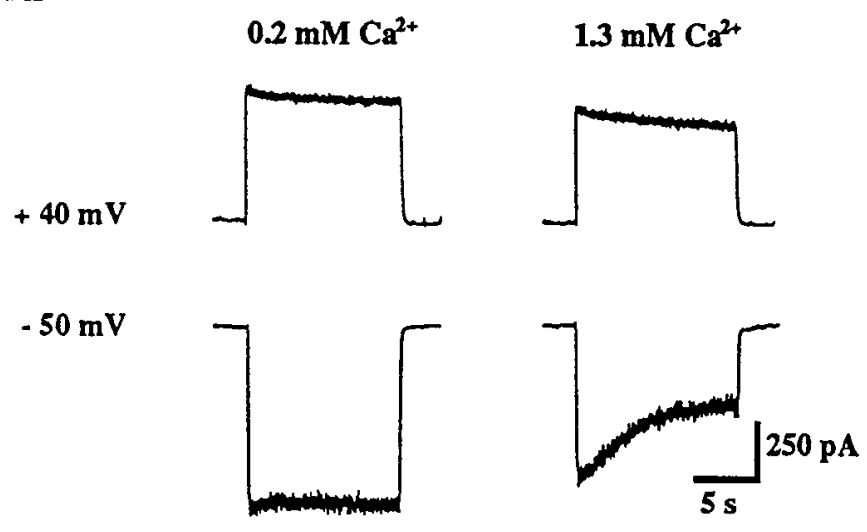

C

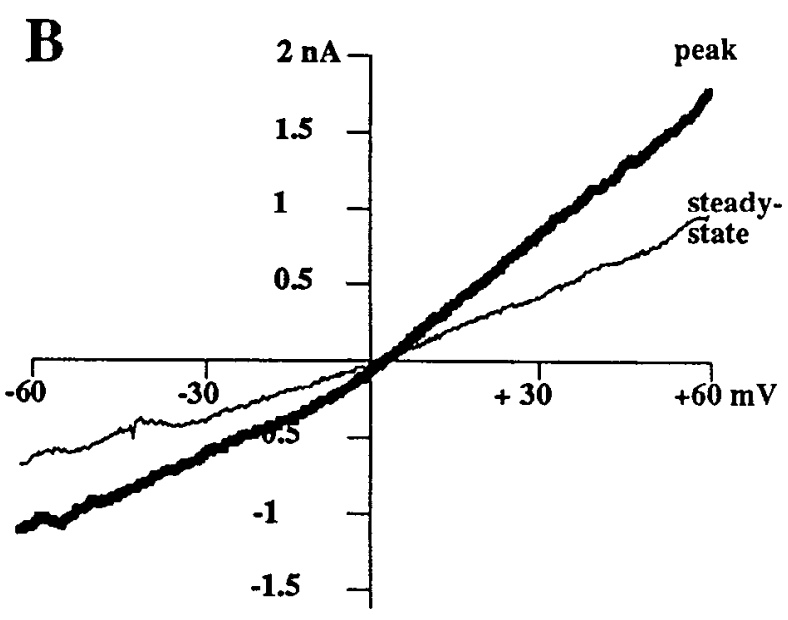

Figure 1. Characteristics of calcium-dependent inactivation of NMDA currents. $A$, Whole-cell currents were evoked by flow pipe application of NMDA $(10 \mu \mathrm{M}, 15 \mathrm{sec})$ in either low external calcium $(0.2 \mathrm{~mm}$; left traces) or normal calcium $(1.3 \mathrm{~mm}$; right traces). The current showed no macroscopic descnsitization in low calcium at a holding potential of $-50 \mathrm{mV}$, but in $1.3 \mathrm{~mm}$ calcium the current inactivated slowly following an initial peak, reaching a steady state level of $47 \%$ inactivation for this neuron. The small relaxations seen at $+40 \mathrm{mV}$ were calcium independent. $B$, Calcium-dependent inactivation was not due to a change in the ionic driving force. A $130 \mathrm{msec}$ voltage ramp from $-70 \mathrm{mV}$ to $+60 \mathrm{mV}$ was applied $500 \mathrm{msec}$ after the beginning of the response (thick line), and after inactivation reached steady state at 14.5 sec (thin line). The reversal potential was unchanged. Currents are leak subtracted. $C$, Inactivation was incomplete but involved the entire population of NMDA channels. NMDA $(10 \mu \mathrm{M})$ was applied to a neuron at $-50 \mathrm{mV}$. After steady state of inactivation was reached, the current was irreversibly blocked by a 40 sec application of MK-801 $(10 \mu \mathrm{M})$ in the continuous presence of NMDA (left panel). A subsequent test pulses of NMDA (500 msec, 0.2 mM $\left.\left[\mathrm{Ca}^{2+}\right]_{o}\right) 1$ min after removal of NMDA + MK-801 showed no recovery (trace b, right panel), suggesting that all channels opened at some time during the steady state inactivation period. The test pulse prior to MK-801 is shown in trace $A$, right panel.

msec) obtained at the peak and end of a $15 \mathrm{sec}$ NMDA application (Fig. 1B). The reversal potential was $4.1 \pm 2.7 \mathrm{mV}$ at the peak and $4.3 \pm 2.9 \mathrm{mV}(n-7)$ after the relaxation reached steady state. Of note, the slope conductance was reduced over the entire voltage range, suggesting that recovery from calciumdependent inactivation was slower than the duration of the ramp (see also Fig. 2). Substitution of the impermeant anions gluconate or methylsulfonate for chloride in the intracellular solution also did not affect the degree of $\mathrm{Ca}^{2+}$-dependent inactivation. The inactivation was $47.8 \pm 5.9 \%(n-4)$ with gluconate-containing pipettes and $45.2 \pm 5.3 \%(n=5)$ with methylsulfonatecontaining pipettes, compared to $43.7 \pm 6.4 \%$ with chloridecontaining pipettes ( $n=20$; see Fig. 3 ). Thus, activation of an inward $\mathrm{Ca}^{2+}$-activated chloride current is not responsible for the $\mathrm{Ca}^{2+}$-dependent relaxation under our conditions.

To test whether $\mathrm{Ca}^{2+}$-dependent inactivation was a result of reduced ligand affinity, we measured the relaxation using a supramaximal concentration of NMDA $(300 \mu \mathrm{M})$. At this concentration, a small relaxation $(15.0 \pm 3.3 \%, n=10)$ was seen in the absence of $\left[\mathrm{Ca}^{2+}\right]_{o}$, presumably reflecting an additional form of receptor desensitization (see, e.g., Mayer et al., 1989; Sather et al., 1990). However, in $1.3 \mathrm{~mm}\left[\mathrm{Ca}^{2+}\right]_{o}$, the rclaxation reached $41.6 \pm 11.8 \%(n=10)$ after an NMDA application of $3.5 \mathrm{sec}$. This was slightly less than the steady state inactivation; however, longer drug applications at high agonist concentrations resulted in irreversible channel rundown (see MacDonald et al., 1989). Thus, inactivation is not due to a decrease in agonist affinity.

$\mathrm{Ca}^{2+}$-dependent inactivation was not complete even during prolonged agonist applications, usually approaching a maximum inhibition of $45-50 \%$. This suggested the possibility that $45-50 \%$ of the channels are completely inactivated by calcium and the remainder are calcium insensitive. As MK-801 blocks open NMDA channels but exits extremely slowly from the channel (Huettner and Bean, 1988), we used this property to test for separate channel populations. MK-801 rapidly blocked the steady state NMDA current (Fig. $1 C$, left); however, no recovery was seen to a test NMDA pulse $1 \mathrm{~min}$ following the end of the NMDA + MK-801 application (trace b, Fig. 1C). For four 
neurons, the block at 1 min following NMDA + MK-801 was $97 \pm 2 \%$. In the absence of MK-801, recovery of the NMDA current was complete within $1 \mathrm{~min}$ (not shown; see also Fig. 2). This suggests that channels inactivated by calcium reopen during the $40 \mathrm{sec}$ exposure to NMDA + MK-801, and that most (if not all) of the current is carried by channels that undergo $\mathrm{Ca}^{2+}$-dependent inactivation.

The onset and recovcry from inactivation were examined by a $15 \mathrm{sec}$ exposure to $1.3 \mathrm{~mm}\left[\mathrm{Ca}^{2+}\right]_{o}$ during a prolonged application of NMDA in low $\left[\mathrm{Ca}^{2+}\right]_{o}$. As shown in Figure $2 A$, the onset consisted of a rapid reduction in current resulting from the change in channel conductance followed by a slow relaxation as observed during single applications of NMDA in normal $\left[\mathrm{Ca}^{2+}\right]_{o}$. Following return to low $\left[\mathrm{Ca}^{2+}\right]_{o}$ solutions, there was complete recovery of the current with a half-recovery lime of $22.6 \pm 3.7 \mathrm{sec}(n=13)$. The slow recovery did not appear to result from trapping of $\mathrm{Ca}^{2+}$ ions in the inactivated channel, because full recovery occurred even in the absence of NMDA (Fig. $2 B$ ). In addition, the rate of recovery was not increased during continuous exposure to NMDA. This contrasts with the behavior of slow open channel blockers such as phencyclidine, ketamine, and MK-801 (Huettner and Bean, 1988; Mayer et al., 1988; MacDonald et al., 1991).

\section{Dependence on $\left[\mathrm{Ca}^{2+}\right]$ 。}

Both the maximal inactivation and the rate of inactivation were dependent on the extracellular concentration of calcium. During applications of $10 \mu \mathrm{M}$ NMDA, there was little or no appreciable inactivation during a $15 \mathrm{sec}$ application in the absence of added $\left[\mathrm{Ca}^{2+}\right]_{o}$; however, the addition of $0.2,0.6$, and $1.3 \mathrm{mM}\left[\mathrm{Ca}^{2+}\right]_{o}$ produced a dose-dependent increase in inactivation (Fig. $3 \mathrm{~A}$ ). Inactivation was $9.6 \pm 11 \%$ at $0.2\left[\mathrm{Ca}^{2+}\right]_{0}(n=14), 29.2 \pm 2.4$ $\%$ at $0.6 \mathrm{~mm}\left[\mathrm{Ca}^{2+}\right]_{o}(n=6)$, and $43.7 \pm 6.4 \%$ at $1.3 \mathrm{~mm}\left[\mathrm{Ca}^{2+}\right]_{o}$ $(n=20)$. There was no further increase in inactivation when the $\left[\mathrm{Ca}^{2+}\right]_{o}$ was increased to $10 \mathrm{~mm}$ (Fig. $3 B$ ). In some neurons, there appeared to be a slight delay in the onset of inactivation at low concentrations of $\left[\mathrm{Ca}^{2+}\right]_{o}$, as is apparent in Figure $3 \mathrm{~A}$. However, the time constant of inactivation $\left(\tau_{\text {inact }}\right)$ at $1.3 \mathrm{~mm}$ $\left[\mathrm{Ca}^{2+}\right]_{o}$ was generally well fitted with a single exponential of 4.7 $\pm 0.6 \mathrm{sec}(n=11 ;$ Fig. $3 C)$. The $\tau_{\text {inact }}$ decreased as $\left[\mathrm{Ca}^{2+}\right]_{0}$ increased; that is, the rate of inactivation was accelerated. Although the degree of inactivation was maximal at $1.3 \mathrm{~mm}\left[\mathrm{Ca}^{2+}\right]_{o}$, $\tau_{\text {inact }}$ continued to decrease, reaching $2.5 \pm 0.7 \mathrm{sec}(n=8)$ and $1.2 \pm 0.3 \mathrm{sec}(n=7)$ at 10 and $50 \mathrm{~mm}\left[\mathrm{Ca}^{2+}\right]_{o}$, respectively (Fig. $3 D$ ). Increasing the concentration of NMDA to $100 \mu \mathrm{M}$ resulted in a left shift of the calcium concentration-response curve. Inactivation was $28.5 \pm 2.6 \%(n=4)$ at $0.2 \mathrm{mM}\left[\mathrm{Ca}^{2+}\right]_{o}, 41.5 \pm$ $2.8 \%(n=5)$ at $0.6 \mathrm{mM}\left[\mathrm{Ca}^{2+}\right]_{o}$, and $46.6 \pm 3.0 \%(n=5)$ at 1.3 $\mathrm{mM}\left[\mathrm{Ca}^{2+}\right]_{0^{\text {. }}}$.

\section{Dependence on $\left[\mathrm{Ca}^{21}\right]_{\mathrm{i}}$}

NMDA channels are calcium permeable; thus, $\mathrm{Ca}^{2+}$-dependent inactivation could result from accumulation of intracellular calcium. Although the experiments above were performed using intracellular buffering with $10 \mathrm{~mm}$ EGTA, the increased inactivation at high concentrations of agonist suggested that the degree and rate of inactivation were dependent on the buffer capacity in the cell. As BAPTA is a much more rapid and selective $\mathrm{Ca}^{2+}$ buffer, we examined inactivation during dialysis with $15 \mathrm{~mm}$ BAPTA. As shown in Figure $4 A$, there was no apparent inactivation during a $15 \mathrm{sec}$ application of $10 \mu \mathrm{M}$ NMDA at $1.3 \mathrm{~mm}\left[\mathrm{Ca}^{2+}\right]_{\sigma}$. However, the effect of BAPTA could be
A
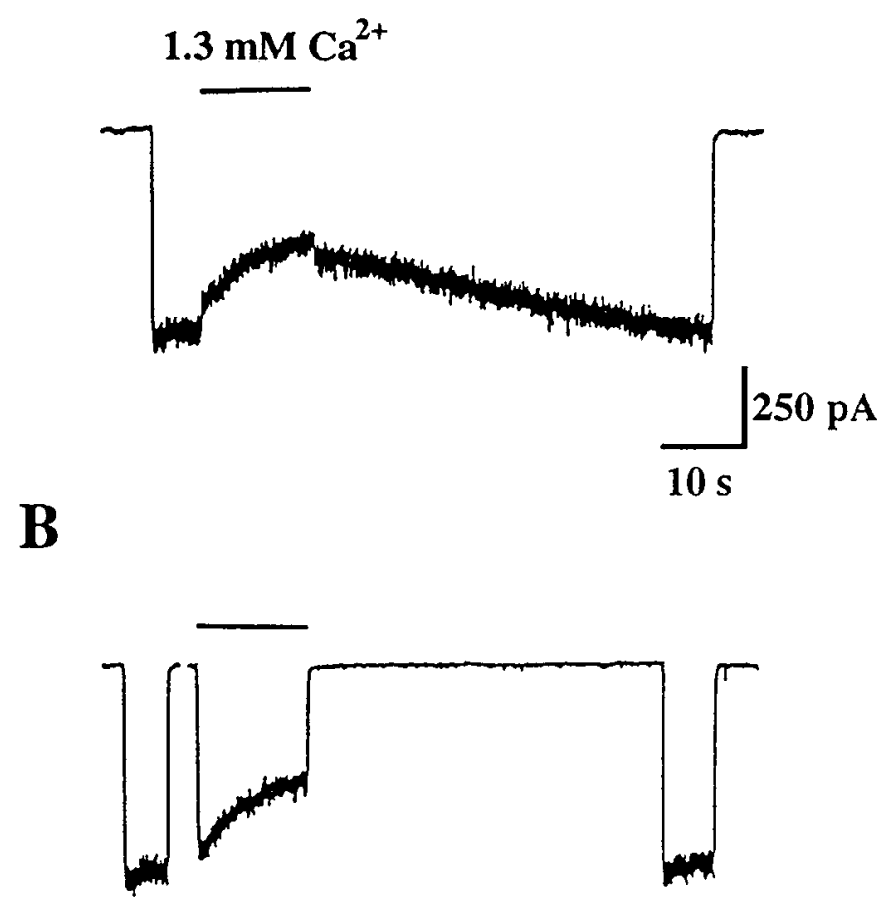

Figure 2. Inactivation was reversible on removal of extracellular calcium. $A$, During a long application of NMDA (10 $\mu \mathrm{M}, 70 \mathrm{sec}),\left[\mathrm{Ca}^{2+}\right]_{o}$ was increased from 0.2 to $1.3 \mathrm{~mm}$ for $15 \mathrm{sec}$. This was accompanied by an instantaneous reduction in current (due to the reduced singlechannel conductance) followed by slow $\mathrm{Ca}^{2+}$-dependent inactivation. On return to the low-calcium solution, recovery was complete. The recovery followed a nonexponential time course with a half-recovery time of $\approx 20 \mathrm{sec}$. $B$, Channel activation did not accelerate the recovery rate (compare $A$ with $B$ ), suggesting that closed channel block was not responsible for inactivation. NMDA $(10 \mu \mathrm{M})$ was applied in $0.2 \mathrm{Ca}^{2+}$ before, and $50 \mathrm{sec}$ after, a $15 \mathrm{sec}$ application of NMDA in $1.3 \mathrm{mM} \mathrm{Ca}^{2+}$. As in $A$, recovery was complete.

overcome by raising the $\left[\mathrm{Ca}^{2+}\right]_{o}$ to $10 \mathrm{~mm}$. For the neuron shown in Figure $4 A$, the inactivation was $51.6 \%$ with a time constant of $3.8 \mathrm{sec}$; similar results were obtained on six neurons. This also suggests that $\mathrm{H}^{+}$or $\mathrm{Mg}^{2+}$ transients, resulting from exchange with $\mathrm{Ca}^{2+}$ bound to EGTA, do not trigger inactivation.

As noted above, $\tau_{\text {inact }}$ was dependent on $\left[\mathrm{Ca}^{2+}\right]_{o}$. This could result from the kinetics of a $\mathrm{Ca}^{2}$ binding site or could simply reflect the rate of accumulation of calcium at an intracellular effector site near the channel. Our results suggest the latter, as reducing EGTA from 10 to $0.1 \mathrm{~mm}$ produced a marked decrease in $\tau_{\text {inact }}$ (Fig. $4 B$ ). The $\tau_{\text {inact }}$ was $1.7 \pm 0.1 \sec (n=6)$ at $0.1 \mathrm{~mm}$, which was only slightly slower $(p<0.02)$ than $\tau_{\text {inact }}$ in the absence of added buffer (1.2 $\pm 0.2 \mathrm{sec}, n=7)$.

These results strongly suggest that an intracellular calcium transient following the opening of NMDA channels is responsiblc for inactivation. Thus, we tested whether inactivation could be occluded by tonic increases in $\left[\mathrm{Ca}^{2+}\right] i$. $\mathrm{Ca}^{2+}$-dependent inactivation was examined in cells dialyzed with either $1 \mu \mathrm{M} \mathrm{Ca}^{2+}$ $\left(=10 \mathrm{mM} \mathrm{Ca}^{2+}+11 \mathrm{~mm}\right.$ EGTA) or $1 \mathrm{mM} \mathrm{Ca}^{2+}(=10 \mathrm{~mm}$ EGTA $+11 \mathrm{~mm} \mathrm{Ca}^{2+}$ ). As shown in Figure $4 C$, the percentage inactivation was significantly less using the high-calcium patch solutions compared to control cells dialyzed with $10 \mathrm{~mm}$ EGTA with no added calcium. Inactivation was $26.4 \pm 5.8 \%(n=6$, $p<0.01)$ for $1 \mu \mathrm{M} \mathrm{Ca}{ }^{2+}$ and $18.4 \pm 8.9 \%(n=5, p<0.01)$ for $1 \mathrm{mM} \mathrm{Ca}^{2+}$. This compares to $43.7 \pm 6.7 \%(n=20)$ inactivation 
A

Figure 3. Maximal inactivation and the inactivation rate were dependent on the extracellular calcium concentration. $A$, The currents evoked by NMDA $(10 \mu \mathrm{M})$ in $0.2,0.6$, and $1.3 \mathrm{~mm}\left[\mathrm{Ca}^{2+}\right]_{0}$ were normalized to the initial peak and superimposed. The inactivation progressively increased from a $27 \%$ reduction in $0.6 \mathrm{~mm}$ to $41 \%$ in $1.3 \mathrm{~mm}\left[\mathrm{Ca}^{2+}\right.$ 。 for this neuron. $B$, The percentage inactivation is shown as a function of extracellular calcium. The nominally calcium-free solution had an estimated calcium concentration of $20 \mu \mathrm{M}$. Inactivation was measured at the end of a $15 \mathrm{sec}$ application of NMDA $(10 \mu \mathrm{M})$. Each point is the average of 6-20 neurons. Intracellular buffer was $10 \mathrm{~mm}$ EGTA with no added calcium. The data were fitted with the logistic equation $I$ $=I_{\max } * 1 /\left(1+\left(\mathrm{IC}_{-50} /\left[\mathrm{Ca}^{2+}\right]_{0}\right)^{n}\right.$, where $I$ $=$ percentage inactivation and $I_{\max }=$ maximal inactivation $(45.2 \%)$. The halfmaximal inactivation $\left(\mathrm{IC}_{50}\right)$ was $411 \mu \mathrm{M}$ with a slope factor $(n)$ of 1.97. $C$, Inactivation was reasonably well fitted by a single exponential with a time constant of $\approx 4 \mathrm{sec}$ in $1.3 \mathrm{~mm}\left[\mathrm{Ca}^{2+}\right]_{\circ}(10$ mм EGTA buffering). $D$, Increases in $\left[\mathrm{Ca}^{2+}\right]_{0}$ above $1.3 \mathrm{~mm}$ accelerated the inactivation time constant without altering the maximal inactivation. Each point is the average of 6-11 neurons.

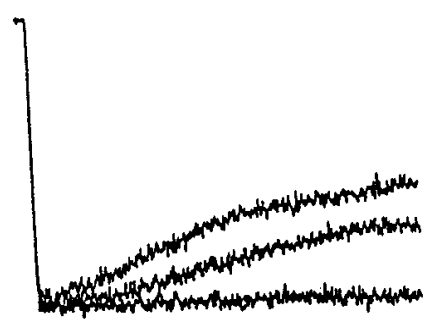

B

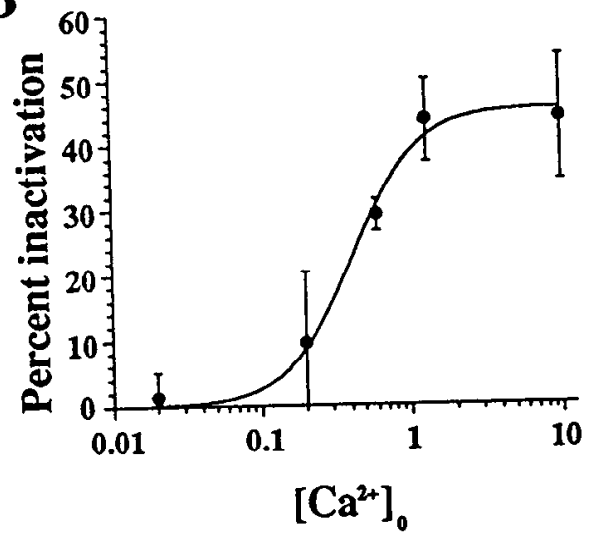

C

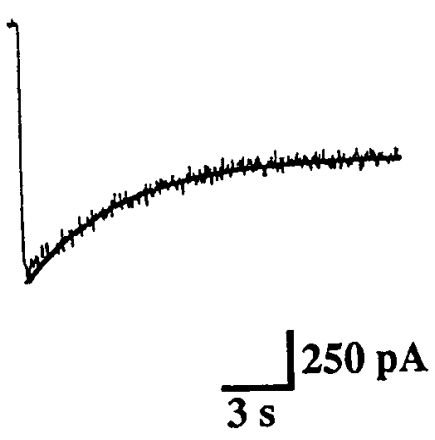

D

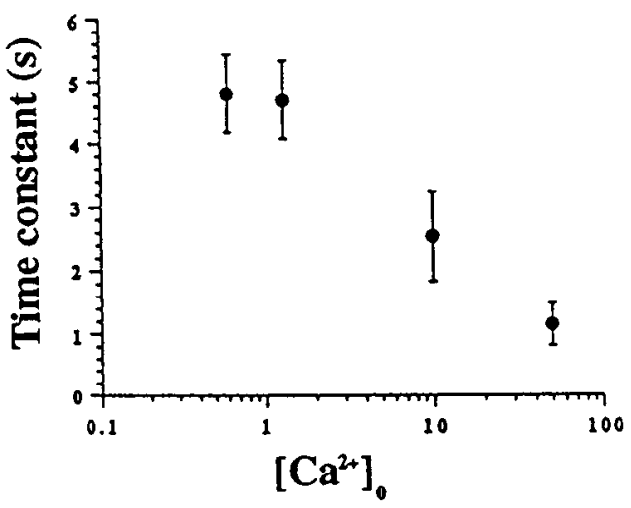

in control conditions (see Fig. 3B). This is the cxpceted result if high intracellular calcium tonically inactivates NMDA channels. The $\tau_{\text {inact }}$ was also decreased (Fig. 4C) similar to cells with low concentrations of EGTA (Fig. 4C), indicating a rapid accumulation of free calcium. It was somewhat surprising that inactivation was not completely occluded even with $1 \mathrm{~mm} \mathrm{Ca}^{2+}$ in the pipette solution; that is, in the virtual absence of a calcium gradient, $\left[\mathrm{Ca}^{2+}\right]_{o}=1.3 \mathrm{~mm}$. Thus, the free calcium concentration in the submembrane compartment is likely to be less than in the pipette solution, presumably reflecting continuing clearance of calcium via transmembrane pumps and exchangers.

Under physiological conditions, several sources may contribute to increases in cytoplasmic calcium including voltage- and ligand-gated channels as well as release of calcium from intracellular stores (e.g., Miller, 1991). We examined whether calcium flux through voltage-gated calcium channels could also induce inactivation of NMD $\Lambda$ channels. Increases in cytoplasmic calcium were elicited either by voltage jumps or by prepulses of NMDA in $\mathrm{Ca}^{2+}$-containing medium. The prepulse was followed by a test pulse of NMDA in $\mathrm{Ca}^{2+}$-free medium. As shown in Figure $5 A$, a $240 \mathrm{msec}$ voltage step to $+10 \mathrm{mV}\left(5 \mathrm{~mm}\left[\mathrm{Ca}^{2+}\right]_{0}\right)$ produced a sustained inward calcium current. Following 250 msec in calcium-free medium, the NMDA current activated by the test pulse was inhibited by $32.0 \pm 9.8 \%(n-14)$. The reduction in the size of the NMDA current could be attributed to transmembrane calcium influx, as steps to $+70 \mathrm{mV}$ near the $\mathrm{Ca}^{2+}$ equilibrium potential had no effect. The inhibition of the tcst pulsc of NMDA was immediate, but then decreased during the pulse, presumably reflecting clearance of calcium from the effector site. Prepulses of NMDA ( $\left.50 \mu \mathrm{M}, 5 \mathrm{mM} \mathrm{Ca}^{2+}, 150 \mathrm{msec}\right)$ in $\mathrm{Ca}^{2+}$-containing medium produced a similar degree of inhibition $(34.0 \pm 8.9 \%, n=6$; Fig. $5 B)$. This could not be attributed to $\mathrm{Ca}^{2+}$-independent desensitization, as there was little macroscopic desensitization following application of $50 \mu \mathbf{M}$ NMDA with $\left[\mathrm{Ca}^{21}\right]_{o}=0$.

Although NMDA channels are calcium permeable, the calcium flux represents only a fraction of the total current (Mayer and Westbrook, 1987) compared to the high selectivity of the calcium channel (Lee and Tsien, 1984). However, charge transfer was $114 \pm 35 \mathrm{pC}$ compared to $249 \pm 58 \mathrm{pC}$ for the prepulse of NMDA. If calcium entry through $\mathrm{Ca}^{2+}$ channels was equally effective in producing inactivation of the NMDA channel, this would require that $45 \%$ of the NMDA current was carried by calcium ions. This is much in excess of the estimates from the GHK current equation (Mayer and Westbrook, 1987), and suggests that the $\mathrm{Ca}^{2+}$ influx through NMDA channels is more effective.

The recovery from inhibition following a voltage step to +10 $\mathrm{mV}$ is shown in Figure $5 \mathrm{C}$. Recovery had a time constant of $12.7 \pm 6.3 \sec (n=3)$ with a final recovery of $88 \pm 11 \%(n=$ 4). This was more rapid than recovery from $\mathrm{Ca}^{3+}$-depcndent inactivation produced by long application of NMDA (see Fig. 2). These observations suggest that calcium entry, not receptor activation, is responsible for inactivation. 


\section{0 mM EGTA}

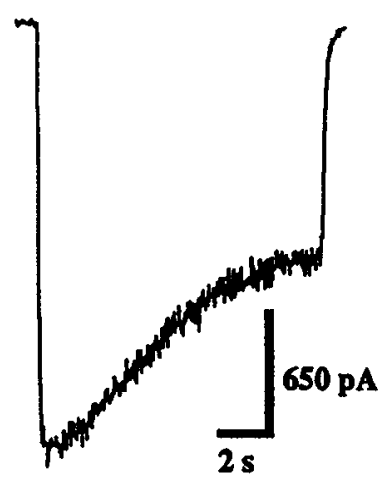

$$
1 \mu \mathrm{M}\left[\mathrm{Ca}^{2+}\right]_{1}
$$

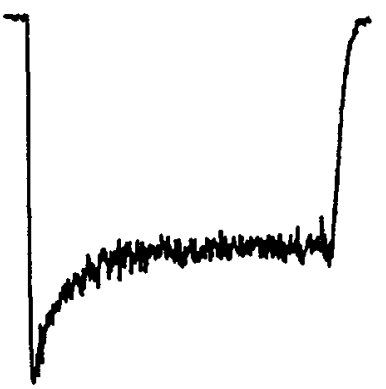

$1 \mathrm{mM}\left[\mathrm{Ca}^{2+}\right]_{1}$

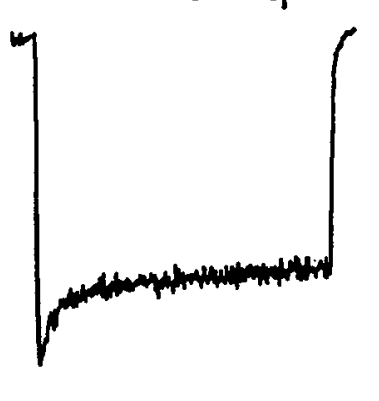

Figure 4. Intracellular calcium buffering also influenced inactivation. $A$, Inactivation was significantly reduced using BAPTA compared to EGTA in the whole-cell pipette. For this neuron, there was little inactivation in $1.3 \mathrm{mM}\left[\mathrm{Ca}^{2+}\right]_{o}$ in the presence of $15 \mathrm{~mm}$ BAPTA. However, even buffering with $15 \mathrm{~mm}$ BAPTA could be overcome with increases in $\left[\mathrm{Ca}^{2+}\right]_{o}$ to $10 \mathrm{~mm}$, resulting in maximal $(\approx 50 \%)$ inactivation. $B$, The $\tau_{\text {inact }}$ decreased when EGTA was reduced to $0.1 \mathrm{mM}$ or omitted from the whole-cell pipette. $\left[\mathrm{Ca}^{2+}\right]_{o}$ was $1.3 \mathrm{~mm}$. This suggests that $\tau_{\text {inact }}$ reflects primarily the rate of $\left[\mathrm{Ca}^{2+}\right]_{i}$ accumulation. Each point is the average of $6-20$ cells. Data for $10 \mathrm{mM}$ EGTA are the same as shown in Figure $3 D$ for $1.3 \mathrm{~mm}\left[\mathrm{Ca}^{2+}\right]_{o}$. $C$, $\mathrm{Ca}^{2+}$-dependent inactivation was also reduced by increasing the buffered concentration of calcium in the whole-cell dialysate to $1 \mu \mathrm{M}$ (11 EGTA + $10 \mathrm{~mm}$ $\left.\mathrm{Ca}^{2+}\right)$ or $1 \mathrm{~mm}(10 \mathrm{EGTA}+11 \mathrm{~mm}$ $\mathrm{Ca}^{2+}$ ). The control patch solution contained $10 \mathrm{~mm}$ EGTA with no added calcium. $\left[\mathrm{Ca}^{2+}\right]_{0}$ was $1.3 \mathrm{mM}$, and $5 \mathrm{~min}$ of whole-cell dialysis preceded application of NMDA. With high intracellular calcium, the percentage inactivation was markedly reduced and $\tau_{\text {inact }}$ decreased. Examples from three neurons are shown.

\section{Divalent selectivity and role of $\mathrm{Ca}^{2+}$-dependent enzymes}

In addition to $\mathrm{Ca}^{2+}$, several other divalent cations including $\mathrm{Ba}^{2+}, \mathrm{Sr}^{2+}$, and $\mathrm{Mn}^{2+}$ can permeate the NMDA channel (Mayer and Wcstbrook, 1987; Ascher and Nowak, 1988). However, most $\mathrm{Ca}^{2+} /$ calmodulin-dependent enzymes show marked selectivity for $\mathrm{Ca}^{2+}$ compared to other divalent cations (Chao et al., 1984). For example, the $\mathrm{Ca}^{2+}$-dependent phosphatase that dephosphorylates voltage-dependent calcium currents cannot be activated by barium (Chad and Eckert, 1986). However, in our experiments, $\mathrm{Ba}^{2+}$ and $\mathrm{Sr}^{2+}$ were partially effective in mimicking $\mathrm{Ca}^{2}$-dependent inactivation of NMDA channels. The results for one neuron are shown in Figure 6; the peak current varied according to the predicted slope conductances for these divalents (Mayer and Westbrook, 1987). In the presence of $1.3 \mathrm{~mm}\left[\mathrm{Ba}^{2+}\right]$ or [ $\left.\mathrm{Sr}^{2+}\right]$, inactivation was $28.4 \pm 1.4 \%(n=7)$ and $27.2 \pm 2.2 \%$ $(n=8)$, respectively. This was significantly less than that due to equimolar $\mathrm{Ca}^{2+}$ on the same neurons $(41.4 \pm 4.5 \%, n=8)$. For the neuron shown in Figure 6, $\tau_{\text {inact }}$ for $\mathrm{Ca}^{2+}$ was $3.9 \mathrm{sec}$ compared to 2.8 and $1.3 \mathrm{sec}$ for $\mathrm{Ba}^{2+}$ and $\mathrm{Sr}^{2+}$.

We directly tested whether a protease or phosphatase could be responsible for $\mathrm{Ca}^{2+}$-dependent inactivation. The protease inhibitor leupeptin $(100 \mu \mathrm{M}, n=3)$ had no effect on inactivation when included in the patch pipette. Likewise, inactivation was reversible, inconsistent with a proteolytic mechanism. Several phosphatase inhibitors were also added to the whole-cell pipette and allowed to diffuse into the cell over 10-15 min. Neither the nonselective phosphatase inhibitor $\mathrm{Fl}^{-}(50 \mathrm{~mm})$ nor the type $\mathrm{I} / 2 \mathrm{~A}$ inhibitor okadaic acid $(5 \mu \mathrm{M})$ had any effect on the degree or rate of $\mathrm{Ca}^{2+}$-dependent inactivation $(n=4)$. The percentage inactivation was $44.4 \pm 5.8 \%$ at the beginning of recording compared to $43 \pm 5.7 \%$ following dialysis with okadaic acid. The calmodulin inhibitor calmidazolium $(10 \mu \mathrm{M})$ also had no effect on inactivation in four neurons.

\section{NMDA channel activity in cell-attached patches}

Cell-attached recording provides one method to analyze ion channel regulation without disrupting the intracellular milieu. NMDA-activated channels in cell-attached patches have kinetics similar to outside-out patches (Gibb and Colquhoun, in press). In cell-attached patches from cultured hippocampal neurons, low concentrations of $\mathrm{L}$-glutamate $(1 \mu \mathrm{M})$ activated inward single-channel currents with amplitudes of $3-3.5 \mathrm{pA}$ in normal extracellular $\left[\mathrm{Ca}^{2+}\right]$. The channels were absent when $\mathrm{L}$-glutamate was omitted from the pipette solution or when $50 \mu \mathrm{M} 2$-amino5 -phosphonovalerate was added $(n=5)$, consistent with selective activation of NMDA channels. Depolarization of the patch resulted in outward single potassium channel currents, but these were rare at a command potential of $0 \mathrm{mV}$ (the cell resting potential). Although the cell membrane potential was not controlled, measurement of the reversal potential of the NMDA channels gave a predicted resting potential of -60 to $-70 \mathrm{mV}$.

The goal of these experiments was to assess the effect of increases in cytoplasmic calcium on NMDA channels in the patch. To eliminate calcium flux through channels in the patch, the cell-attached pipette contained $10 \mathrm{~mm}$ EGTA. In the absence of $\left[\mathrm{Ca}^{2}{ }^{\prime}\right]_{\text {, }}$, the single-channel current was $4.5-5 \mathrm{pA}$. When the cell was briefly depolarized with $5 \mathrm{sec}$ pulses of either $150 \mathrm{mM}$ 
Figure 5. The onset of inactivation required less than $500 \mathrm{msec}$. $A$, Voltage jump from a holding potential of -50 $\mathrm{mV}$ (240 msec; $V_{c}=+10 \mathrm{mV} ;\left[\mathrm{Ca}^{2+}\right]_{o}$ $=5 \mathrm{~mm}$ ) resulted in an inward calcium current. Following a delay of $250 \mathrm{msec}$ in $\mathrm{Ca}^{2+}$-free medium, the NMDA current $\left(10 \mu \mathrm{M},\left[\mathrm{Ca}^{2+}\right]_{0}=0\right)$ was instantaneously reduced by $40 \%$ in this neuron. However, a voltage jump to the calcium equilibrium potential $(+70$ $\mathrm{mV}$ ) evoked an outward current, but had no effect on the NMDA current amplitude. The NMDA current following the jump to $+70 \mathrm{mV}$ is superimposed on the current in the absence of a voltage prepulse. The whole-cell pipette contained $1 \mathrm{~mm}$ EGTA with no added calcium and $100 \mu \mathrm{M}$ leupeptin. $B, A$ brief pulse of NMDA $(50 \mu \mathrm{M})$ in $\mathrm{Ca}^{2+}$-containing medium $(5 \mathrm{~mm})$ also caused a rapid inhibition of the test NMDA pulse. Conditions were the same as for $A$. $C$, Recovery from inactivation was monitored by 300 msec NMDA pulses in $\mathrm{Ca}^{2+}$-free medium. Test pulses immediately preceding $(a)$, and following $(b)$, a $250 \mathrm{msec}$ voltage jump to $+10 \mathrm{mV}$ (see $A$ ) are shown in the left panel. Recovery was nearly complete $(88 \%)$ at $60 \mathrm{sec}$ following the voltage pulse (right panel).
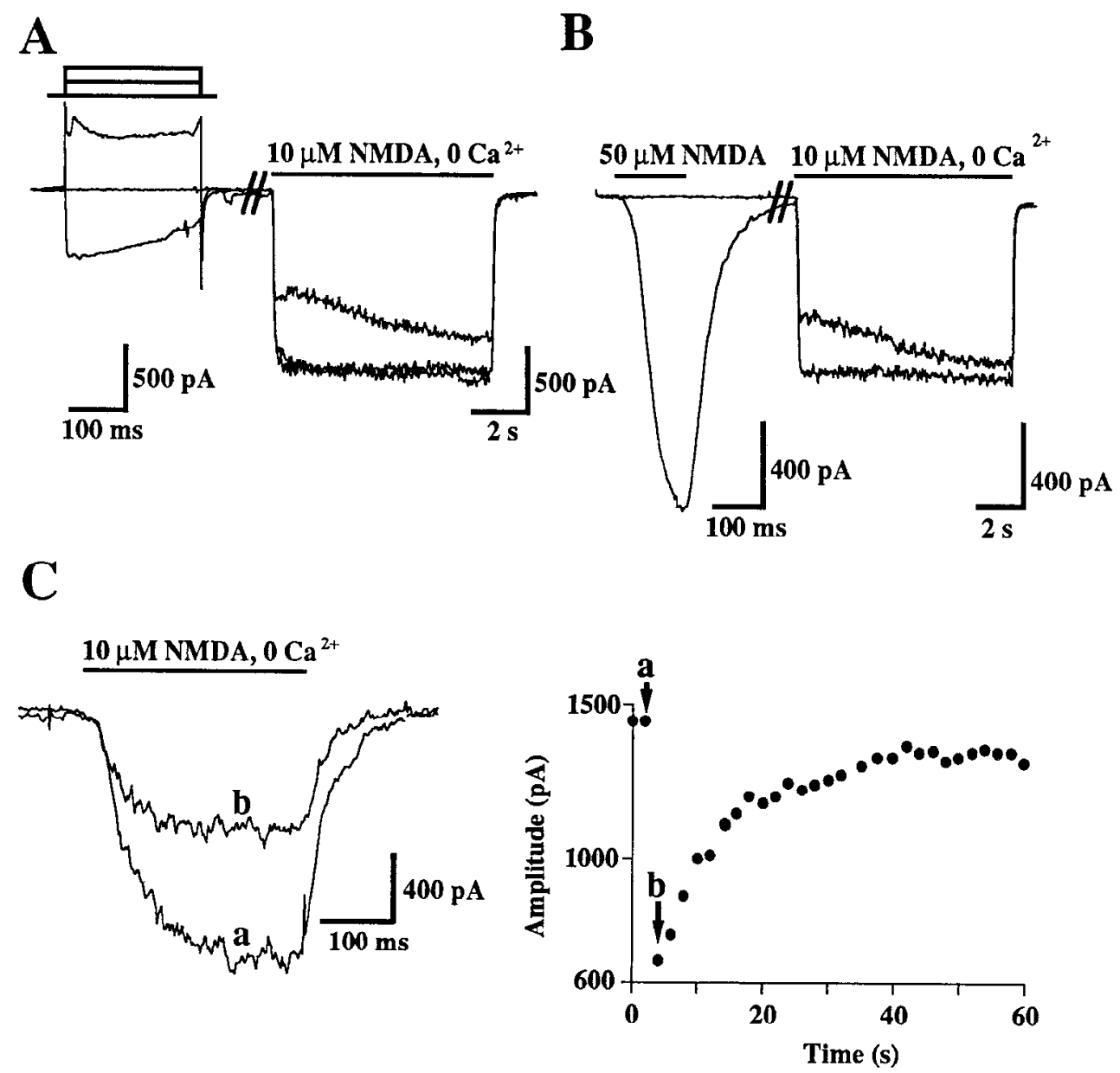

$\mathrm{KCl}+5 \mathrm{mM} \mathrm{Ca}^{2+}$, or NMDA $(100 \mu \mathrm{M})+5 \mathrm{mM} \mathrm{Ca}^{2+}$, there was an abrupt outward current and disappearance of NMDA channels as the driving force collapsed. Following removal of the $\mathrm{KCl}$ solution, the membrane potential was quickly restored as indicated by the return of the single-channel current to its basal level (Fig. 7A). However, the activity of NMDA channels in the patch was markedly decreased. Similar decreases in activity with applications of $\mathrm{KCl}$ or NMDA were not seen when the pipette solutions contained $1.3 \mathrm{mM}\left[\mathrm{Ca}^{2+}\right]$. This suggests that the continuous activity of NMDA channels in the patch is suf-

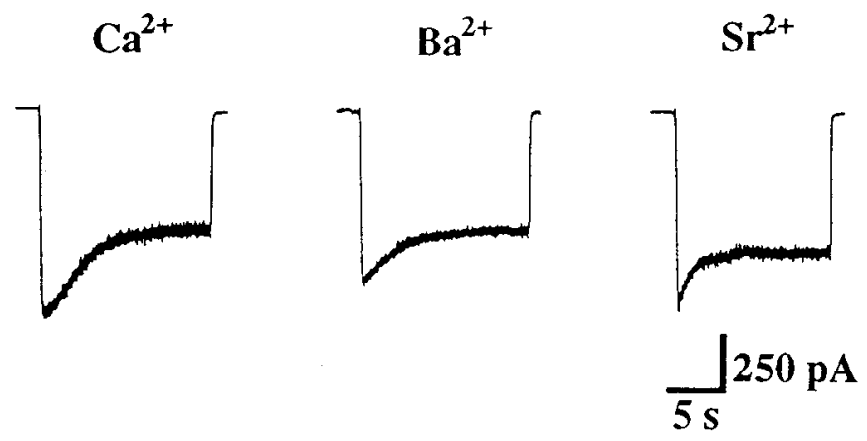

Figure 6. Barium and strontium are less effective than calcium. NMDA $(10 \mu \mathrm{M})$ was applied in the presence of $\left[\mathrm{Ca}^{2+}\right]_{o}, \mathrm{Ba}^{2+}$, or $\mathrm{Sr}^{2+}$, all at 1.3 mM. Responses are from one neuron at a holding potential of $-50 \mathrm{mV}$. The percentage inactivation was $41.8 \%, 29 \%$, and $23.8 \%$, respectively. The $\tau_{\text {inact }}$ was decreased for $\mathrm{Ba}^{2+}$ and $\mathrm{Sr}^{2+}$ compared to $\mathrm{Ca}^{2+}$ (see text). ficient to induce maximal $\mathrm{Ca}^{2+}$-dependent inactivation, and that depolarization alone cannot account for the decrease in channel activity.

The amplitude histograms immediatcly before and after $\mathrm{KCl}$ are shown in Figure $7 B$; the probability dropped from 0.64 to 0.26 . The time course of the drop in channel activity after $\mathrm{KCl}$ application was estimated by calculating the probability in $1 \mathrm{sec}$ epochs. For the patch shown in Figure $7 C$, the activity returned to baseline levels within $15 \mathrm{sec}$. For three patches, the inhibition was $57 \pm 8 \%$, which was similar to the maximal inactivation in whole-cell recording.

\section{Discussion}

Our results demonstrate that intracellular calcium leads to inactivation of the NMDA channel. The rate and degree of inactivation were related to the influx and clearance of intracellular calcium, and inactivation could be triggered by opening of either NMDA or voltage-dependent calcium channels. Inactivation was unaltered by phosphatase inhibitors, suggesting that dephosphorylation of the channel does not underlie $\mathrm{Ca}^{2+}$ dependent inactivation.

\section{$\mathrm{Ca}^{2+}$-dependent inactivation results from increases in intracellular calcium}

Several distinct mechanisms appear to underlie desensitization of NMDA channels. At submaximal concentrations of glycine, glutamate binding results in an allosteric reduction in glycine affinity with subsequent unbinding of glycine and channel clo- 

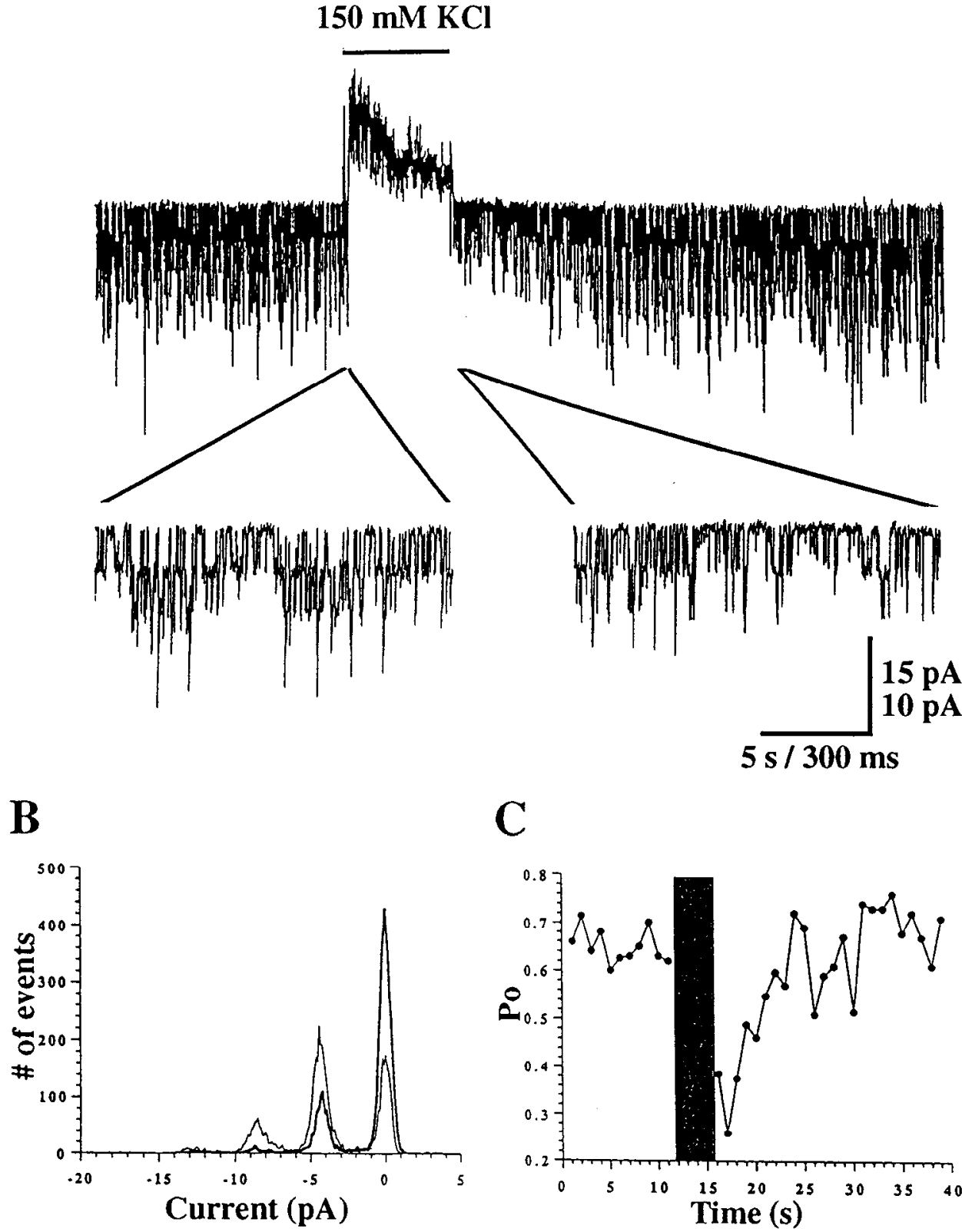

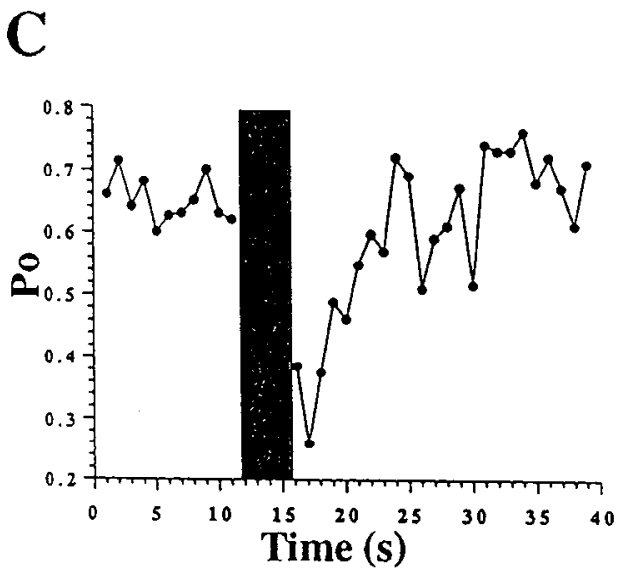

Figure 7. $\mathrm{Ca}^{2+}$-dependent inactivation is present in intact cells. $A$, In cellattached recording, L-glutamate $(1 \mu \mathrm{M})$ activated inward single-channel currents of $4.5 \mathrm{pA}\left(165 \mathrm{mM} \mathrm{Na}^{+}, 0 \mathrm{Ca}^{2+}\right)$; the patch pipette contained $10 \mathrm{~mm}$ EGTA with no added $\mathrm{Ca}^{2+}$ to eliminate $\mathrm{Ca}^{2+}$ influx through channels in the patch. The patch was clamped at $0 \mathrm{mV}$. The cell membrane potential was determined by measuring the channel reversal potential, which was usually ncar $-60 \mathrm{mV}$ for stable patches. Cell depolarization ( $5 \mathrm{sec}, 150 \mathrm{~mm} \mathrm{KCl}, 5 \mathrm{~mm}$ $\mathrm{Ca}^{2+}$ ) caused an abrupt outward current. Following removal of the depolarizing stimulus, the membrane potential quickly returned, as indicated by the return of the single-channel current amplitude to its basal level. However, the activity of NMDA channels in the patch was transiently decreased. Onesecond epochs immediately before and after $\mathrm{KCl}$ are shown on an expanded time scale. $B$, Point-by-point amplitude histogram of data segment immediately before (thin line) and after $\mathrm{KCl}$ (thick line) show the drop in the current peaks at 4.4 and $8.8 \mathrm{pA}$. The open probability dropped from 0.64 to 0.26 . $C$, Time course of recovery of NMDA channel activity is plotted in $1 \mathrm{sec}$ epochs. The half-recovery time was $8 \mathrm{sec}$ for this patch. Solid bar indicates period of $\mathrm{KCl}$ application. Same patch as $A$ and $B$. sure (i.e., glycine-dependent "desensitization"; Mayer et al., 1989). However, in outside-out membrane patches, prominent glycine-independent desensitization leads to $\geq 90 \%$ loss of the evoked current (Sather et al., 1990; Lester and Jahr, 1992). Profound glycine-independent desensitization also appears in whole-cell recording of small or acutely dissociated neurons (Sather et al., 1990; Zilberter et al., 1991). Neither of these phenomena contributed to the $\mathrm{Ca}^{2+}$-dependent inactivation seen in our experiments because glycine was used at saturating concentrations, and macroscopic glycine-independent desensitization was small, representing at most $20 \%$ of the peak current at high agonist concentrations. In addition, no macroscopic desensitization was observed with the low agonist concentrations (e.g., $10 \mu \mathrm{M}$ NMDA) used.

The first indication that calcium might inactivate NMDA channels came from voltage-clamp studies of cultured spinal cord neurons (Mayer and Westbrook, 1985). Subsequent ex- periments using the calcium indicator dye arsenazo III also suggested that increases in intracellular calcium could decrease NMDA responses (Mayer et al., 1987). However, recently it has been suggested that the calcium acts at an extracellular site to enhance receptor desensitization (Clark et al., 1990). Increases in extracellular calcium do reduce the conductance of NMDA channels (Jahr and Stevens, 1987; Mayer and Westbrook, 1987; Ascher and Nowak, 1988), but this process is instantaneous and thus clearly distinguishable from the slow inactivation observed in our experiments. Our evidence strongly favors an intracellular site of action for inactivation. Both the degree and rate of inactivation were dependent on the extracellular $\left[\mathrm{Ca}^{2+}\right]$, but this was highly dependent on the concentration of EGTA in the whole-cell pipette. Lowering the EGTA concentration would be expected to increase the rate of accumulation of intracellular free calcium. Thus, the decrease in $\tau_{\text {inact }}$ as the EGTA concentration was decreased (or $\left[\mathrm{Ca}^{2+}\right]_{o}$ increased) suggests that ac- 
cumulation of $\left[\mathrm{Ca}^{2+}\right] i$ determines the inactivation rate. Similar results were seen with BAPTA, excluding the possibility that intracellular protons or $\mathrm{Mg}^{2+}$ (Johnson and Ascher, 1990) is responsible for inactivation. However, even strong buffering with high concentrations of BAPTA could be overcome when the calcium influx was sufficiently large. This may explain the failure of other investigators to see a dependence on intracellular buffering (e.g., Clark et al., 1990).

Calcium-dependent inactivation had several characteristic features. The inactivation was slow and was enhanced at negative holding potentials that could be explained by calcium influx through open NMDA channels (Mayer et al., 1987). Although we did not determine the calcium sensitivity of the intracellular site, even quite high pipette calcium concentrations did not completely occlude inactivation. This may suggest that the site of calcium action has a relatively low affinity. This would predict a rapid off-rate; thus, the slow recovery from inactivation suggests that $\left[\mathrm{Ca}^{2+}\right] i$ clearance is the rate-limiting step in recovery. Inactivation was maximal at physiological levels of extracellular calcium and also was present in intact cells as measured by cell-attached recording. Thus, inactivation may be an important process during normal synaptic transmission. Inactivation was also incomplete, reaching a steady state near $50 \%$ of the peak current; however, this could not be explained by complete inactivation of a subpopulation of channels, although a small population of $\mathrm{Ca}^{2+}$-insensitive channels cannot be excluded.

\section{Comparison to $\mathrm{Ca}^{2+}$-dependent inactivation of other ion channels}

Desensitization or inactivation of several ligand-gated ion channels is calcium dependent. In the case of calcium-permeable channels this could serve as a regulatory mechanism. Although the molecular action of calcium is not known in all cases, several mechanisms appear to be involved. Manthey (1966) first reported increases in desensitization of the muscle $\mathrm{ACh}$ receptor (AChR) by increases in $\left[\mathrm{Ca}^{2+}\right]_{o}$, which were subsequently attributed to incrcascs in intraccllular calcium (Scubon-Mulieri and Parsons, 1977). However, this has not been observed in all preparations (Anwyl and Narahashi, 1980) and potentiation of neuronal AChRs via an extracellular action of $\mathrm{Ca}^{2+}$ has also been reported (Vernino et al., 1992). Increases in intracellular calcium can also suppress $\mathrm{GABA}_{\mathrm{A}}$ receptors in some neurons (Inoue et al., 1986; Behrends et al., 1988; but see Shirasaki et al., 1992). Phosphorylation enhances muscle AChR desensitization, and it has been proposed that calcium entry through the channels could activate protein kinase $C$ leading to ${ }^{\circ}$ channel phosphorylation (reviewed in Huganir and Greengard, 1990). On the other hand, rundown of $\mathrm{GABA}_{\mathrm{A}}$ currents in hippocampal neurons is accelerated by intracellular calcium, suggesting a role for dephosphorylation by a $\mathrm{Ca}^{2+} /$ calmodulin-dependent phosphatase (Chen et al., 1990).

Perhaps the best-studied examples of calcium-dependent inactivation are L-type calcium channels in molluscan neurons (Chad et al., 1984). Channel activity in these cells is dependent on cAMP-dependent phosphorylation. Inactivation by intracellular calcium appears to result from $\mathrm{Ca}^{2+}$-dependent dephosphorylation, as it is mimicked by perfusion with the $\mathrm{Ca}^{2+}$. dependent phosphatase calcineurin (Armstrong, 1989; Chad, 1989). An additional irreversible component is blocked by leupeptin, suggesting an additional component due to a $\mathrm{Ca}^{2+}$-dependent protease (Chad and Eckert, 1986). $\mathrm{Ca}^{2+}$-dependent en- zymes have also been suggested as contributing to calcium channel inactivation in GH3 cells and guinea pig myocytes (Belles et al., 1988; Kalman et al., 1988). Although $\mathrm{Ca}^{2+}$-dependent inactivation of the NMDA currents is similar in many of the criteria proposed for inactivation of molluscan calcium channels (Chad, 1989), the mcchanisms differ in two important respects. First, $\mathrm{Ca}^{2+}$-dependent inactivation of NMDA currents does not appear to involve phosphatases, and was fully reversible, suggesting that proteases are not involved. Second, equimolar substitution of $\mathrm{Ca}^{2+}$ with $\mathrm{Ba}^{2+}$ or $\mathrm{Sr}^{2+}$ is partially effective in producing inactivation. $\mathrm{Ba}^{2+}$ and $\mathrm{Sr}^{2+}$ have larger ionic radii and thus are less effective agonists than $\mathrm{Ca}$ in stimulating calmodulin-dependent processes (Chao et al., 1984). $\mathrm{Ba}^{21}$ and $\mathrm{Sr}^{21}$ did evoke relaxations that were more rapid than $\mathrm{Ca}^{2+}$, perhaps suggesting that buffering and clearance mechanisms are also less efficient in handling divalents other than calcium (see, e.g., Ahmed and Connor, 1979). Thus, a mechanism other than dephosphorylation appears to underlie $\mathrm{Ca}^{2+}$-dependent inactivation of the NMDA receptor. However, this does not exclude the possibility that the NMDA channel can be phosphorylated, as the NR-1 subunit does have a consensus $\mathrm{Ca}^{2+} /$ calmodulinkinase II/protein kinase $\mathrm{C}$ phosphorylation site (Moriyoshi et al., 1991), and protein kinase $\mathrm{C}$-dependent potentiation of NMDA responses has been reported (Chen and Huang, 1991).

\section{Mechanism and site of action of intracellular calcium}

Other than dephosphorylation, calcium could conceivably act by direct binding to the channel, by binding to regulatory proteins, or by screening negative charges on the membrane. Although our experiments do not directly address these possibilities, they provide constraints on the possible mechanisms and site of action. For example, neither ligand binding nor channel opening was required to elicit $\mathrm{Ca}^{2+}$-dependent inactivation, suggesting that the putative binding site is accessible from the cytoplasm, but unlikely to be deep within the channel pore. Likewise, inactivation was not overcome by increasing the agonist concentration; thus, a competitive reduction in the affinity of ligand binding is excluded. Recovery also continued in the presence of agonist when extracellular calcium was removed, unlike the use dependence that occurs with closed channel block (e.g., Huettner and Bean, 1988). Intracellular $\mathrm{Mg}^{2+}$ can bind within the NMDA channels and reduce its conductance, but $\mathrm{Ca}^{2+}$ even at $1 \mathrm{mM}$ did not produce this effect (Johnson and Ascher, 1990). In our experiments, the $I-V$ relationship of the inactivated wholecell current was unchanged from control, which excludes a voltage-dependent block by an intracellular divalent cation as the cause of inactivation. The reversal potential of the inactivated current was also unchanged; thus, membrane charge screening by $\left[\mathrm{Ca}^{2+}\right] i$ at concentrations that induce inactivation must be negligible. The calcium-induced reduction in channel activity in cell-attached patches suggests an alteration in channel gating with no apparent effect on single-channel conductance. Overall, our results are consistent with an allosteric binding site on the channel, but do not exclude an action on a $\mathrm{Ca}^{2+}$-dependent regulatory protein.

Although the site of calcium action does not appear to be within the channel pore, calcium influx through NMDA channels was more effective in the induction of inactivation than influx through voltage-dependent calcium channels. This suggests that the site of calcium action is relatively near the intraccllular domain of the receptors. Although the relative distribution of voltage-dependent calcium and NMDA channels is 
unknown, several observations suggest compartmentalization of intracellular calcium transients following activation of glutamate channels (Malenka et al., 1988; Müller and Connor, 1991). This may involve either channel location or variations in calcium clearance in different compartments (Guthrie et al., 1991). Although an action of calcium near the channel might be expected to have a rapid onset, inactivation was slow during NMDA applications due to the time required for calcium accumulation. Maximal inactivation could occur in $\leq 500 \mathrm{msec}$ following rapid increases in $\left[\mathrm{Ca}^{2+}\right] i$ by voltage steps. An interesting possibility is that calcium accumulation leads to progressive changes in channel gating, as has been proposed for calcium-mediated inactivation of voltage-dependent calcium channels (Yue et al., 1990). This could also be significant during high-frequency stimulation of excitatory synapses in the hippocampus.

\section{Role of high-energy phosphates}

The activity of NMDA channels during whole-cell recording has been reported to require high-energy phosphates possibly for direct receptor phosphorylation (MacDonald et al., 1989). We have also noted loss of NMDA current in the absence of ATP ("rundown"), and thus an ATP regeneration solution was included in our experiments. Under these conditions, the NMDA current was stable for recording periods up to 30-60 min. However, in the absence of ATP, not only did the peak current decrease, but there was a nearly complete loss of the $\mathrm{Ca}^{2+}$ dependent relaxation (Rosenmund et al., 1991). This could mean that a channel that has "run down" is no longer subject to $\mathrm{Ca}^{2+}$ dependent inactivation, or that rundown itself is a $\mathrm{Ca}^{2+}$-dependent phenomenon as has been reported for $\mathrm{GABA}_{\mathrm{A}}$ channels (Chen et al., 1990), and in our preliminary experiments with NMDA channels (Rosenmund et al., 1991). The second possibility might indicate that ATP is required simply to enable the clearance of calcium from the cytoplasm by the $\mathrm{Na} / \mathrm{Ca}$ exchanger and calcium pump (Blaustein, 1988; Carafoli, 1991). Thus, intracellular $\mathrm{Ca}^{2+}$ may play a central role in the regulation of NMDA channels and provide negative feedback control over calcium influx into dendritic spines.

\section{References}

Ahmed Z, Connor JA (1979) Measurement of calcium influx under voltage clamp in molluscan neurones using the metallochromic dye arsenazo III. J Physiol (Lond) 286:61-82.

Aıwyl R, Narahashi T (1980) Desensitization of the acetylcholine receptor of denervated rat soleus muscle and the effect of calcium. $\mathrm{Br}$ J Pharmacol 69:91-98.

Armstrong DL (1989) Calcium channel regulation by calcineurin, a $\mathrm{Ca}^{2+}$-activated phosphatase in mammalian brain. Trends Neurosci 12:117-122.

Armstrong DL, Rossier MF, Shcherbatko AD, White RE (1991) Enzymatic gating of voltage-activated calcium channels. Ann NY Acad Sci 635:26-34.

Ascher P, Nowak L (1988) The role of divalent cations in the $N$ methyl-D-aspartate responses of mouse central neurones in culture. $\mathrm{J}$ Physiol (Lond) 399:247-266.

Behrends JC, Maruyama T, Tokutomi N, Akaike N (1988) $\mathrm{Ca}^{2+}$ mediated suppression of the GABA-response through modulation of chloride channel gating in frog sensory neurones. Neurosci Lett 86; 311-316.

Belles B, Hescheler J, Trautwein W, Blomgren K, Karlsson JO (1988) A possible physiological role of the $\mathrm{Ca}$-dependent protease calpain and its inhibitor calpastatin on the $\mathrm{Ca}$ current in guinea pig myocytes. Pfluegers Arch 412:554-556.

Blaustein MP (1988) Calcium transport and buffering in neurons. Trends Neurosci 11:438-443.
Carafoli E (1987) Intracellular calcium homeostasis. Annu Rev Biochem 56:395-433.

Carafoli E (1991) The calcium pumping ATPase of the plasma membrane. Annu Rev Physiol 53:531-547.

Chad J (1989) Inactivation of calcium channels. Comp Biochem Physiol 93A:95-105.

Chad J, Eckert R, Ewald D (1984) Kinetics of calcium-dependent inactivation of calcium current in voltage-clamped neurones of $A p l y$ sia californica. J Physiol (Lond) 347:279-300.

Chad JE, Eckert R (1986) An enzymatic mechanism for calcium current inactivation in dialysed Helix neurones. J Physiol (Lond) 378: $31-51$

Chao S-H, Suzuki Y, Zysk JR, Cheung WY (1984) Activation of calmodulin by various metal cations as a function of ionic radius. Mol Pharmacol 26:75-82.

Chen L, Huang Y-YM (1991) Sustained potentiation of NMDA receptor-mediated glutamate responses through activation of protein kinase $C$ by a $\mu$ opioid. Neuron 7:319-326.

Chen QX, Stelzer A, Kay AR, Wong RKS (1990) GABA $_{A}$ receptor function is regulated by phosphorylation in acutely dissociated guineapig hippocampal ncurones. J Physiol (Lond) 420:207-221.

Choi DW (1988) Glutamate neurotoxicity and diseases of the nervous system. Neuron 1:623-634.

Clark GD, Clifford DB, Zorumski CF (1990) The effect of agonist concentration, membrane voltage and calcium on $N$-methyl-D-aspartate receptor desensitization. Neuroscience 39:787-797.

Collingridge GL, Lester RAJ (1989) Excitatory amino acid receptors in the vertebrate central nervous system. Pharmacol Rev 40:143-210.

Forscher P, Oxford GS (1985) Modulation of calcium channels by norepinephrine in internally dialyzed avian sensory neurons. J Gen Physiol 85:743-763.

Gibb AJ, Colquhoun D (in press) Activation of NMDA receptors by L-glutamate in cells dissociated from adult rat hippocampus. J Physiol (Lond), in press.

Guthrie PB, Segal M, Kater SB (1991) Independent regulation of calcium revealed by imaging dendritic spines. Nature 354:76-80.

Huettner JE, Bean BP (1988) Block of $N$-methyl-D-aspartate-activated current by the anticonvulsant MK-801: selective binding to open currents. Proc Natl Acad Sci USA 85:1307-1311.

Huganir RL, Greengard P (1990) Regulation of neurotransmitter receptor desensitization by protein phosphorylation. Neuron 5:555567.

Inouc M, Oomura Y, Yakushiji T, Akaike N (1986) Intracellular calcium ions decrease the affinity of the GABA receptor. Nature 324: $156-158$.

Jahr CE, Stevens CF (1987) Glutamate activates multiple single channel conductances in hippocampal neurons. Nature 325:522-525.

Johnson JW, Ascher P (1990) Voltage-dependent block by intracellular $\mathrm{Mg}^{2+}$ of $N$-methyl-D-aspartate-activated channels. Biophys J 57:10851090.

Kalman D, O'Lague PH, Erxleben C, Armstrong DL (1988) Calciumdependent inactivation of the dihydropyridine-sensitive calcium channels in $\mathrm{GH}_{3}$ cells. J Gen Physiol 92:531-548.

Korn SJ, Horn R (1989) Influence of sodium-calcium exchange on calcium current rundown and the duration of calcium-dependent chloride currents in pituitary cells, studied with whole cell and perforated patch recording. J Gen Physiol 94:789-812.

Lee KS, Tsien RW (1984) High selectivity of calcium channels in single dialysed heart cells of the guinea-pig. J Physiol (Lond) 354: 253-272.

Legendre P, Westbrook GL (1990) The inhibition of single $N$-methylD-aspartate-activated channels by zinc ions on cultured rat neurones. J Physiol (Lond) 429:429-449.

Lester RAJ, Jahr CE (1992) NMDA channel behavior depends on agonist affinity. J Neurosci 12:635-643.

Llinas R, Sugimori M, Silver RB (1992) Microdomains of high calcium concentrations in a presynaptic terminal. Science 256:677-679.

Lynch G, Seubert P (1989) Links between long-term potentiation and neuropathology. Ann NY Acad Sci 568:171-180.

MacDonald JF, Mody I, Salter MW (1989) Rcgulation of $N$-methyl$\mathrm{D}$-aspartate receptors revealed by intracellular dialysis of murine neurones in culture. J Physiol (Lond) 414:17-34.

MacDonald JF, Bartlett MC, Mody I, Pahapill P, Reynolds JN, Salter MW, Schneiderman JH, Pennefather PS (1991) Actions of ketam- 
ine, phencyclidine and MK-801 on NMDA receptor currents in cultured mouse hippocampal neurones. J Physiol (Lond) 432:483-508.

Malenka RC, Kauer JA, Zucker RS, Nicoll RA (1988) Postsynaptic calcium is sufficient for potentiation of hippocampal synaptic transmission. Science 242:81-84.

Manthey AA (1966) The effect of calcium on the desensitization of membrane receptors at the neuromuscular junction. J Gen Physiol 49:963-976.

Marchenko SM (1991) Mechanism of modulation of GABA-activated current by internal calcium in rat central neurons. Brain Res 546: 355-357.

Marty A (1989) The physiological role of calcium-dependent channels. Trends Neurosci 12:420-424.

Mayer ML, Westbrook GL (1985) The action of $N$-methyl-D-aspartic acid on mouse spinal neurones in culture. J Physiol (Lond) 361:6590.

Mayer ML, Westbrook GL (1987) The physiology of excitatory amino acids in the vertebrate central nervous system. Prog Neurobiol 28: 197-276.

Mayer ML, MacDermott AB, Westbrook GL, Smith SJ, Barker JL (1987) Agonist- and voltage-gated calcium entry in cultured mouse spinal cord neurones under voltage clamp measured using arsenazo III. J Neurosci 7:3230-3244.

Mayer ML, Westbrook GL, Vyklický L Jr (1988) Sites of antagonist action on $N$-methyl-D-aspartate receptors studied using fluctuation analysis and a rapid perfusion technique. J Neurophysiol 60:645-663.

Mayer ML, Vyklický L Jr, Clements J (1989) Regulation of NMDA receptor desensitization in mouse hippocampal neurons by glycine. Nature 338:425-427.

Miller RJ (1991) The control of neuronal $\mathrm{Ca}^{2+}$ homeostasis. Prog Neurobiol 37:255-285.

Moriyoshi K, Masu M, Ishii T, Shigemoto R, Mizuno N, Nakanishi S (1991) Molecular cloning and characterization of the rat NMDA receptor. Nature 354:31-37.

Müller W, Connor JA (1991) Dendritic spines as individual neuronal compartments for synaptic $\mathrm{Ca}^{2+}$ responses. Nature 354:73-76.
Nicoll RA, Kauer JA, Malenka RC (1988) The current excitement in long-term potentiation. Neuron 1:97-103.

Oliva C, Cohen IS, Mathias RT (1988) Calculation of time constants for intracellular diffusion in whole cell patch clamp configuration. Biophys J 54:791-799.

Pusch M, Neher E (1988) Rates of diffusional exchange between small cells and a measuring patch pipette. Pfluegers Arch 411:204-211.

Rosenmund C, Legendre P, Westbrook GL (1991) Rundown of NMDA currents: dependence on ATP and calcium. Soc Neurosci Abstr 17: 957.

Sather W, Johnston JW, Henderson G, Ascher P (1990) Glycineinsensitive desensitization of NMDA responses in cultured mouse embryonic neurons. Neuron 4:725-731.

Scubon-Mulieri B, Parsons RL (1977) Desensitization and recovery at the frog neuromuscular junction. J Gen Physiol 69:431-447.

Shirasaki T, Aibara K, Akaike N (1992) Direct modulation of GABA receptor by intracellular ATP in dissociated nucleus tractus solitarii neurones of rat. J Physiol (Lond) 449:551-572.

Smith SJ, Augustine GJ (1988) Calcium ions, active zones and synaptic transmitter release. Trends Neurosci 11:458-464.

Vernino S, Amador M, Luetje CW, Patrick J, Dani JW (1992) Calcium modulation and high calcium permeability of neuronal nicotinic acetylcholine receptors. Neuron 8:127-134.

Vyklický L Jr, Benveniste M, Mayer ML (1990) Modulation of $\mathrm{N}$ methyl-D-aspartic acid receptor desensitization by glycine in mouse cultured hippocampal neurones. J Physiol (Lond) 428:313-331.

Yue DT, Backx PH, Imredy JP (1990) Calcium-sensitive inactivation in the gating of single calcium channels. Science 250:1735-1738.

Zilberter Y, Uteshev V, Sokolova S, Khodorov B (1991) Desensitization of $N$-methyl-D-aspartate receptors in neurons dissociated from adult rat hippocampus. Mol Pharmacol 40:337-341.

Zorumski CF, Yang J, Fischbach GD (1989) Calcium-dependent, slow desensitization distinguishes different types of glutamate receptors. Cell Mol Neurobiol 9:95-104. 